\title{
Prospects and challenges of environmental DNA (eDNA) monitoring in freshwater ponds
}

\author{
Lynsey R. Harper (1) - Andrew S. Buxton (1) - Helen C. Rees $($ ) Kat Bruce • \\ Rein Brys • David Halfmaerten (D) Daniel S. Read (D) Hayley V. Watson • \\ Carl D. Sayer - Eleanor P. Jones • Victoria Priestley • Elvira Mächler (1) • \\ Cesc Múrria (1) - Sandra Garcés-Pastor • Cecilia Medupin - Katherine Burgess (1) \\ Gillian Benson • Neil Boonham • Richard A. Griffiths • Lori Lawson Handley (D) \\ Bernd Hänfling
}

Received: 22 June 2018/Revised: 20 August 2018/Accepted: 24 August 2018/Published online: 3 September 2018

(C) The Author(s) 2018

\begin{abstract}
Environmental DNA (eDNA) analysis is a rapid, non-invasive, cost-efficient biodiversity monitoring tool with enormous potential to inform aquatic conservation and management. Development is ongoing, with strong commercial interest, and new uses are continually being discovered. General applications of eDNA and guidelines for best practice in freshwater systems have been established, but habitat-specific assessments are lacking. Ponds are highly diverse, yet understudied systems that could benefit from eDNA
\end{abstract}

Handling editor: Eric Larson

Electronic supplementary material The online version of this article (https://doi.org/10.1007/s10750-018-3750-5) contains supplementary material, which is available to authorised users.

L. R. Harper $(\square)$ · H. V. Watson · L. Lawson Handley · B. Hänfling

School of Environmental Sciences, University of Hull, Hull HU6 7RX, UK

e-mail: lynsey.harper2@gmail.com

A. S. Buxton · R. A. Griffiths

School of Anthropology and Conservation, Durrell Institute for Conservation and Ecology, University of Kent, Marlowe Building, Canterbury, Kent CT2 7NR, UK

H. C. Rees

ADAS, School of Veterinary Medicine and Science, The University of Nottingham, Sutton Bonington Campus,

Leicestershire LE12 5RD, UK monitoring. However, eDNA applications in ponds and methodological constraints specific to these environments remain unaddressed. Following a stakeholder workshop in 2017, researchers combined knowledge and expertise to review these applications and challenges that must be addressed for the future and consistency of eDNA monitoring in ponds. The greatest challenges for pond eDNA surveys are representative sampling, eDNA capture, and potential PCR inhibition. We provide recommendations for sampling, eDNA capture, inhibition testing, and laboratory practice, which should aid new and ongoing eDNA projects in ponds. If implemented, these recommendations will contribute towards an eventual broad standardisation of eDNA research and practice, with room to tailor workflows for optimal analysis and

\footnotetext{
K. Bruce

NatureMetrics Ltd, Egham, Surrey TW20 9TY, UK

R. Brys · D. Halfmaerten

Research Institute for Nature and Forest, Gaverstraat 4, 9500 Geraardsbergen, Belgium

D. S. Read

Centre for Ecology \& Hydrology (CEH), Benson Lane, Crowmarsh Gifford, Wallingford,

Oxfordshire OX10 8BB, UK

C. D. Sayer

Pond Restoration Research Group, Department of Geography, Environmental Change Research Centre, University College London, London WC1E 6BT, UK
} 
different applications. Such standardisation will provide more robust, comparable, and ecologically meaningful data to enable effective conservation and management of pond biodiversity.

Keywords Aquatic - Biodiversity - Lentic . Metabarcoding · Quantitative PCR · Survey

\section{Introduction}

Globally, there are an estimated 64 million to 3 billion ponds or small lakes (Downing et al., 2006; Biggs et al., 2016; Hill et al., 2018), with ponds outnumbering larger lentic freshwater systems approximately 100:1 (Downing et al., 2006; Céréghino et al., 2008). Ponds represent a high proportion of global freshwater habitat despite their limited size, comprising up to $30 \%$ of standing freshwater by area (Downing et al., 2006). These small water bodies occur in all land-use types at high frequency (Céréghino et al., 2008) and possess ecological, aesthetic, and recreational value (Biggs et al., 2016). Ponds are species-rich, containing many rare, protected, and unique species not found in other freshwater habitats (Wood et al., 2003; Hill et al., 2018). Moreover, pond networks support more species at landscape-scale than lakes or rivers (Davies et al., 2008).

E. P. Jones · N. Boonham

Fera Science Ltd (Fera), National Agri-food Innovation Campus, Sand Hutton, York YO14 1LZ, UK

V. Priestley

Department of Life Sciences, Imperial College London, Silwood Park, Berkshire SL5 7PY, UK

\section{E. Mächler}

Department of Aquatic Ecology, Eawag: Swiss Federal Institute of Aquatic Science and Technology, Dübendorf, Switzerland

E. Mächler

Department of Evolutionary Biology and Environmental Studies, University of Zurich, Winterthurerstr. 190,

8057 Zürich, Switzerland

C. Múrria

Grup de Recerca Freshwater Ecology and Management (FEM), Departament de Biologia Evolutiva, Ecologia i Ciències Ambientals, Facultat de Biologia, Universitat de Barcelona, Barcelona, Catalonia, Spain
Ponds have enormous scientific value as small and abundant ecosystems along broad ecological gradients, enabling experimental validation and hypothesis testing in ecology and conservation (De Meester et al., 2005). However, until recently, pondscapes - a pond, its immediate catchment, and the terrestrial matrix of land between ponds-were poorly understood (Wood et al., 2003; Hill et al., 2018). Ponds were not mentioned or included in the Water Framework Directive (Davies et al., 2008; Hill et al., 2018) and have been neglected in research, scientific monitoring, and policy (De Meester et al., 2005; Céréghino et al., 2008; Hill et al., 2018), despite being threatened by anthropogenic activity and environmental change, and having greater vulnerability to environmental stressors than larger water bodies with larger catchments (Biggs et al., 2016). Poor study of these important ecosystems may be due in part to a lack of appropriate monitoring tools and sheer abundance (Hill et al., 2018). Pond biodiversity assessment can be costly, time-consuming, and dependent on taxonomic expertise (Briers \& Biggs, 2005; Hill et al., 2018). Often data are at the genus or family-level when species-level knowledge is required for effective conservation.

In this context, molecular tools offer a solution through rapid, sensitive, cost-effective, non-invasive monitoring and promise to enhance our understanding of global biodiversity. One tool, environmental DNA (eDNA) analysis (see Table 1), is particularly relevant

\author{
S. Garcés-Pastor \\ Troms $\emptyset$ University Museum, UiT -The Arctic University \\ of Norway, 9037 Troms $\varnothing$, Norway \\ C. Medupin \\ School of Earth and Environmental Sciences, The \\ University of Manchester, Michael Smith Building, \\ Oxford Road, Manchester M13 9PL, UK \\ K. Burgess \\ Natural England, Westminster, London SW1P, UK \\ G. Benson \\ Natural England, County Hall, Spetchley Road, \\ Worcester WR5 2NP, UK \\ N. Boonham \\ Newcastle University, Newcastle upon Tyne NE1 7RU, \\ UK
}


for aquatic biodiversity monitoring (Rees et al., 2014b; Lawson Handley, 2015; Thomsen \& Willerslev, 2015). Ponds were the first natural habitats screened for macro-organism eDNA by Ficetola et al. (2008), who demonstrated reliable detection of invasive American bullfrogs Lithobates catesbeianus (Shaw, 1802), even at low densities. Since this initial publication, a large and growing number of studies have utilised eDNA in a range of environments (reviewed for example by Rees et al., 2014b; Lawson Handley, 2015; Thomsen \& Willerslev, 2015; Deiner et al., 2017). eDNA approaches are often more affordable and logistically feasible than conventional counterparts, and have enormous potential to enable ecological study at greater temporal and spatial scales (Deiner et al., 2017). However, there are unique challenges associated with using eDNA in ponds that are not faced in other aquatic environments. These challenges are largely due to the physical and chemical properties of ponds that influence eDNA capture and detection, which are not taken into account by current methodologies.

Although eDNA and its applications have been reviewed extensively (Rees et al., 2014b; Barnes \& Turner, 2015; Lawson Handley, 2015; Thomsen \& Willerslev, 2015; Goldberg et al., 2016; Deiner et al., 2017), examinations of eDNA in relation to specific environments are distinctly lacking. In this review, we evaluate eDNA analysis as a tool for biodiversity monitoring in ponds. We first discuss the prospects of eDNA monitoring in these ecosystems. We then identify how ponds differ from other freshwater habitats, and examine the implications this has for eDNA detection. We outline the challenges associated with eDNA analysis in ponds and use the existing literature and combined experience of all authors to provide recommendations that will help standardise eDNA workflows for passive or targeted monitoring of

Table 1 Glossary of technical terms

\begin{tabular}{ll}
\hline Technical term & Definition \\
\hline $\begin{array}{l}\text { Environmental DNA } \\
\text { (eDNA) }\end{array}$ & $\begin{array}{l}\text { Intra- or extracellular DNA that has been shed from an organism (via skin cells, mucus, scales, urine, } \\
\text { faeces, saliva, gametes, or deceased remains) and suspended within an environmental matrix, such as } \\
\text { water, soil, or air (Rees et al., 2014b; Lawson Handley, 2015; Thomsen \& Willerslev, 2015; Deiner } \\
\text { et al., 2017). This DNA can be captured, amplified, identified, and assigned, allowing taxonomic } \\
\text { composition and distribution to be inferred. Current eDNA approaches largely use PCR-based } \\
\text { methods, where DNA is amplified using targeted approaches to detect single-species or non-targeted } \\
\text { approaches to examine community composition (Lawson Handley, 2015) }\end{array}$
\end{tabular}

\section{(PCR)}

Real-time quantitative PCR (qPCR) Droplet digital PCR
(ddPCR)

eDNA metabarcoding

High-throughput sequencing (HTS)

Internal positive control (IPC)
Process used to generate millions of copies (amplify) of a particular section of DNA

PCR and detection are combined in a process which allows users to monitor their amplification reaction as it happens. Fluorescent dyes bind to DNA as it amplifies and the fluorescent signal produced is measured by qPCR instruments. Dyes may be non-specific and bind to any DNA amplified (e.g. SYBR ${ }^{\circledR}$ green) or designed to bind to DNA from a target species (hydrolysis probe). The fluorescent signal of eDNA samples is often quantified against the signal produced by a known amount of synthetic or purified DNA from the target species

A new method of DNA detection, also known as "third-generation PCR", which performs PCR using water-oil emulsion droplet technology. Thousands of nano-litre droplets are generated for each eDNA sample, and thus some ideally contain only one or a few copies of target DNA. Within each of those droplets, an individual PCR reaction occurs and end-point PCR amplification is detected by the fluorescence intensity of a dye (e.g. EvaGreen ${ }^{\circledR}$ ) or probe

A passive community sequencing approach, which enables taxonomic identification of multiple species simultaneously. eDNA samples are amplified with conserved (or universal) primers using PCR, and the PCR products sequenced on a High-Throughput platform

Massively parallel sequencing technologies, such as the Illumina, Roche, or IonTorrent series, which produce millions of sequences for analysis opposed to Sanger sequencing technologies which process one sequence at a time. HTS is also known as Next-Generation Sequencing (NGS)

PCR controls which allow detection of failed DNA extraction or PCR inhibition. Typically, artificial or synthetic DNA not found in biological samples is used, and detected using a different set of primers (and probe) to those used for the target species 
pond biodiversity. Finally, we look into the future of eDNA monitoring in ponds and explore avenues of research that would enhance our understanding of these ecosystems.

\section{Prospects of eDNA monitoring in ponds}

The application of eDNA analysis in ponds (Online Resource 1) and other lentic ecosystems continues to gain popularity, but we are only beginning to realise the potential of this tool in conjunction with ponds for monitoring and research. The most obvious potential is enhanced biological recording and assessment of pond biodiversity. The complementarity of eDNA analysis and conventional methods for monitoring pond biodiversity has been repeatedly demonstrated, and the work of Thomsen et al. (2012) on ponds and other freshwater habitats was pivotal to the development of eDNA surveillance for many rare and endangered species across the globe (e.g. Bylemans et al., 2017; Doi et al., 2017; Niemiller et al., 2017; Torresdal et al., 2017; Weltz et al., 2017). eDNA analysis has since shown potential for estimation of relative abundance and biomass (Takahara et al., 2012; Thomsen et al., 2012; Buxton et al., 2017b), and has begun to outperform conventional counterparts, for example, large-scale sampling and distribution modelling of the threatened great crested newt Triturus cristatus (Laurenti, 1768) (Biggs et al., 2015), and may deepen our understanding of species distribution patterns and activity. This capacity of eDNA analysis to upscale freshwater monitoring and research, particularly ecological hypothesis testing, was reinforced by Harper et al. (2018c), where eDNA metabarcoding (see Table 1) was used in over 500 ponds to identify biotic and abiotic determinants of $T$. cristatus at the UK pondscape.

Ponds are often considered to be closed systems, but may receive inputs from inflow, land surface run-off (especially during high rainfall and flood events), and mobile species (e.g. birds, dragonflies, amphibians, water beetles). In addition, ponds are impacted both directly and indirectly, through large aquatic-terrestrial contact zones, by anthropogenic and environmental stressors. They can therefore act as natural samples of biodiversity in the wider environment, and provide information on entire ecosystems (De Meester et al., 2005). For example, eDNA metabarcoding revealed wildlife using uranium mine containment ponds as water sources, and supplemented conventional assessment of ecotoxicological effects of uranium mining on local biodiversity (Klymus et al., 2017b). Harper et al. (2018c) reaffirmed the data mining potential of eDNA metabarcoding in ponds, where an array of aquatic and non-aquatic biodiversity (60 vertebrate species) was recorded at the UK pondscape.

Beyond a step change in biodiversity monitoring and research, eDNA analysis in ponds offers endless experimental opportunities to heighten understanding of eDNA dynamics due to the vast physical and chemical heterogeneity of these ecosystems. Pond water is comparatively stagnant, and the lack of flow and relatively small water volumes in ponds allows eDNA to accumulate over time to concentrations not attainable in most other water bodies. This has benefits for the amount of target DNA present and subsequent detection probability (Buxton et al., 2017a). However, eDNA accumulation can reduce ability to distinguish contemporary from recent or historic presence (Rees et al., 2014b). Under stagnant conditions, eDNA can settle out of suspension, but become incorporated into the water column again following sediment disturbance (Turner et al., 2015; Buxton et al., 2018). Therefore, eDNA may remain detectable in ponds for several weeks under 'optimal' conditions (Buxton et al., 2017a), but can also degrade rapidly with complete disappearance of target eDNA within 1 week (Brys, R. \& Halfmaerten, D., unpublished results). Ponds are further influenced by the activity of domestic and wild animals which can increase suspended solids within the water column and change the properties of an eDNA sample. These external influences may also transfer eDNA between water bodies and potentially cause false positive detections (Klymus et al., 2017b).

The small and shallow nature of ponds subjects these systems to more extreme conditions than deeper water bodies, including larger fluctuations in temperature range and potentially greater exposure to ultraviolet (UV) light, although higher turbidity and dense vegetation in some ponds will limit UV light penetration (Kazanjian et al., 2018). Temperature, UV light, and $\mathrm{pH}$ all influence eDNA shedding and degradation rates, and can affect the amount of eDNA present within a waterbody (Strickler et al., 2015; Robson et al., 2016; Buxton et al., 2017b; Goldberg et al., 
2018). Many ponds are successional in nature and often support an abundant emergent and semi-terrestrial vegetation with substantial (relative to waterbody size) shallow marginal drawdown zones in some cases, creating ideal habitat for multiple invertebrate and amphibian species. As water volume decreases over time, ponds become increasingly ephemeral or seasonal (Wood et al., 2003). Accessing these waters via wet, vegetated margins may make cross-contamination (see Online Resource 2 for potential sources and their mitigation) between sites hard to avoid, while high levels of organic debris in late succession ponds and duckweed-dominated (Lemna spp.) ponds can exacerbate difficulties in collecting clean, debrisfree samples.

Crucially, ponds can be highly anoxic due to poor wind-mixing and mass decomposition of terrestrial, submerged, and emergent vegetation, resulting in extremely low oxygen content at the bottom of the water column (Sayer et al., 2013; Kazanjian et al., 2018). Anoxic conditions were shown to slow marine eDNA decay (Weltz et al., 2017) but impacts of anoxia on pond eDNA have not been investigated. Slow decay may affect inferences made from eDNA regarding contemporary species presence; however, anoxic conditions dramatically enhance preservation of pond sediments and the communities that live there, providing information on historical pond biodiversity (Alderton et al., 2017; Emson et al., 2017).

\section{Challenges, considerations, and recommendations for eDNA monitoring in ponds}

A universal methodology for eDNA analysis may not be appropriate across habitat types as water bodies vary considerably in their biological, physical, and chemical properties (Goldberg et al., 2016). These fundamental differences can affect eDNA behaviour, including origin, state, fate, and transport (Barnes \& Turner, 2015), and may ultimately have repercussions for eDNA detection. However, no reviews to date examine eDNA in the context of a single freshwater habitat and the challenges specific to this environment. The characteristics of ponds that make them ideal systems for eDNA monitoring and research are the very characteristics that challenge eDNA analysis. It is likely no one standard workflow will be appropriate in all circumstances. Practitioners and researchers must instead determine the most appropriate workflow options on a study-by-study basis. Figure 1 outlines these options and other considerations that must be taken into account throughout the eDNA workflow.

\section{Sampling}

The distribution and dispersion of eDNA in ponds complicates the design of sampling strategies. In contrast to lotic systems, eDNA has a patchy distribution in lentic systems due to an uneven distribution of organisms (Takahara et al., 2012; Eichmiller et al., 2014). This unevenness may reflect available microhabitats in ponds (Nicolet et al., 2004), to what spatial extent these are used by individuals of a species, and what they are used for, i.e. feeding, reproduction (Goldberg et al., 2018). eDNA distribution and dispersion in ponds is limited both horizontally by the presence of barriers to water movement, such as fallen trees and dense stands of aquatic vegetation (Biggs et al., 2015), and vertically by chemical stratification of the water column due to minimal wind-mixing (Sayer et al., 2013). This large variation in eDNA on fine spatial scales has severe consequences for species detection. Eichmiller et al. (2014) detected common carp Cyprinus carpio (Linnaeus, 1758) eDNA at points within tens of metres where it went undetected in a small lake. A lake experiment with caged Northern pike Esox lucius (Linnaeus, 1758) also revealed a substantial reduction $(\sim 80 \%)$ in eDNA detection probability as distance from cages increased (Dunker et al., 2016). More recent caging experiments of fish and amphibians in ponds revealed a strong decrease in eDNA detection probability with distance from the cage, with most species nearly undetectable after a few metres (Brys, R. \& Halfmaerten, D., unpublished data; Li, J. et al., unpublished data). We recommend water is collected underneath or around barriers to eDNA dispersion, and at different depths in ponds to maximise species detection.

The patchy distribution of pond eDNA means one sample of surface water will not sufficiently represent true biodiversity. Representation can be achieved with a timely, thought-out sampling strategy that accounts for location, number and volume of samples, and method of collection. Crucially, ecology of target species should be taken into consideration when choosing sampling time frame and methodology. 


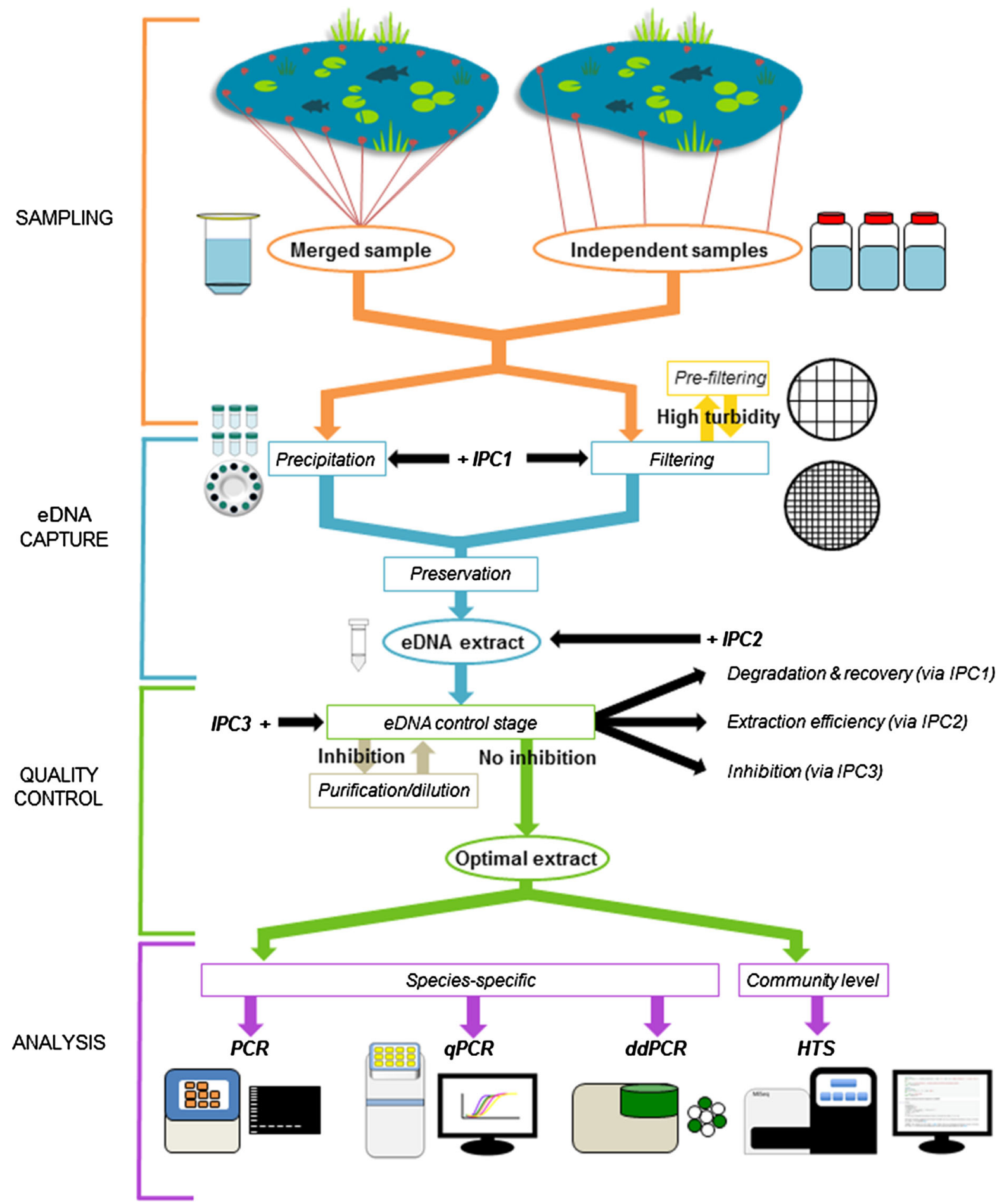

Fig. 1 Schematic of eDNA workflow for samples collected from ponds. Three different Internal Positive Controls (IPCs) are recommended for inclusion during the stages of eDNA capture and quality control to identify substandard samples which require reanalysis or resampling. Pre-filtering is recommended if water samples are turbid 
There is a strong evidence base linking eDNA detection and concentration to life stage, condition, seasonality, and behaviour of species. Over 9 months, Buxton et al. (2017b) identified T. cristatus eDNA concentration in ponds was highest near the end of adult breeding activity and when larval abundance peaked, whereas eDNA concentration decreased with reduced adult body condition (a consequence of reproduction) as well as metamorphosis and dispersal of larvae. Furthermore, T. cristatus eDNA detection probability is substantially lower in autumn and winter outside the breeding season despite year-round detection in water and sediment (Rees et al., 2017; Buxton et al., 2018). Similar decreases in eDNA concentration over the breeding season were observed for the smooth newt Lissotriton vulgaris (Linnaeus, 1758) in ditches and drainage channels (Smart et al., 2015), and the eastern hellbender Cryptobranchus alleganiensis alleganiensis (Daudin, 1803) in streams (Spear et al., 2015; Takahashi et al., 2018). In streams and rivers, eDNA detection probabilities of the black warrior waterdog Necturus alabamensis (Viosca, 1937) and the flattened musk turtle Sternotherus depressus (Tinkle \& Webb, 1955) were also influenced by sampling season and were consistent with current knowledge on timing of foraging and reproduction in these species (de Souza et al., 2016). More recent research demonstrated eDNA concentration and subsequent detection probability of fish may be improved during the spawning season when gametes are released into the water (Bylemans et al., 2017; Tillotson et al., 2018). Seasonal effects on detection probability may be even more pronounced in invertebrates, which release DNA less readily than vertebrates (Tréguier et al., 2014). In a Scottish loch with confirmed signal crayfish Pacifastacus leniusculus (Dana, 1852) presence, Harper et al. (2018a) did not detect eDNA in November, but achieved detection in July. In November, P. leniusculus individuals have spawned but go into torpor inside refuges, as opposed to July when eggs have hatched and individuals actively moult. Based on the aforementioned studies, it is essential for practitioners and researchers to account for and utilise existing knowledge of species behaviour or activity in the design of eDNA surveys to minimise false negatives and maximise detection probability. This is especially important in surveys of ponds due to the variety of concurrent and asynchronous species these systems host throughout the year.
Comprehensive sampling, at many different locations on fine spatial scales, will be required for pond eDNA surveys (Goldberg et al., 2018). There are two main options: collection of stratified or random subsamples around a pond, or sampling/subsampling locations known to be suitable for target species. Samples may be combined for preservation, eDNA capture, and analysis, or processed independently as biological replicates (Fig. 1). The chosen strategy will be context-dependent as surveyors must ensure their targeted or merged sample(s) are representative of their focal species. For example, T. cristatus detection may be best achieved through collection of $20 \times 30 \mathrm{ml}$ samples which are combined and homogenised before $6 \times 15 \mathrm{ml}$ subsamples are taken for subsequent DNA extraction and quantitative PCR (qPCR, see Table 1) analysis (Biggs et al., 2015). Volume and number of samples are standardised with this protocol, but whether all or any aspects would be effective for other species or different applications is unclear. Indeed, Harper et al. (2018b) observed lower $T$. cristatus detection with eDNA metabarcoding than qPCR using this protocol. For information on entire communities, it may be better to take stratified samples around a pond and process these as biological replicates (Evans et al., 2017). Independent sample processing is also necessary to investigate species distribution and habitat use in ponds. We advocate that eDNA studies include sample-based rarefaction to evaluate sample size required to fully represent pond biodiversity.

Limited accessibility to a waterbody can hamper optimisation of sampling strategies for aquatic environments, particularly ponds. Typically, the full pond perimeter may be inaccessible due to distance from the shoreline, areas of dense vegetation, high steep banks, or other risks to health and safety. Sampling poles, boats, or drones (aerial or aquatic) can enable water sample collection beyond the shoreline, but routine use is prevented by expense of purchase and operation (Barnes \& Turner, 2015) and their potential for transfer of contaminants (see Online Resource 2) between ponds. Therefore, surveyors are often unable to systematically sample the full pond perimeter or areas most suitable for focal species, and instead can only collect samples where access can be gained. This may influence detection rates but as yet, there is no evidence to support or refute this. Better insights to the confidence and resolution of eDNA detection in ponds 
could be obtained if surveyors report the total size of the pond perimeter and proportion that was inaccessible, the number of samples and distance at which these were taken, and volume of water collected per sample.

It is not uncommon for ponds to undergo summer drying, causing a reduction in water volume (Nicolet et al., 2004) which may complicate sample collection. In some extremes, ponds completely dry out in summer months, reducing suitability for fully aquatic species and preventing any sample collection. However, ponds may still be used by semi-aquatic species earlier in the season (Nicolet et al., 2004); thus, dry ponds should not be automatically deemed negative for a target species when no sample can be collected (Buxton et al., 2018). In these circumstances, eDNA samples from sediment may provide better insight as to which species utilise a pond, provided method of eDNA capture is appropriate and cautious inferences are made regarding species detection (Turner et al., 2015; Buxton et al., 2018).

\section{eDNA capture}

Two broad methods are used in the capture of eDNA: filtration or ethanol precipitation. Comparative studies have generally shown that filtration approaches have higher sample throughput and can process greater water volumes, thereby increasing potential to recover greater amounts of DNA (Spens et al., 2016; Hinlo et al., 2017; Klymus et al., 2017b). However, studies tend to exclude ponds and make comparisons for water from rivers, lakes, and experimental aquaria.

Since ponds can contain high levels of suspended solids and algae as well as organic debris from detached, degrading aquatic and terrestrial vegetation, filters tend to become blocked when sampling comparatively small water volumes (Klymus et al., 2017b; Raemy \& Ursenbacher, 2018). Where water is turbid, centrifugation, increased pore size, or pre-filtering will be necessary (Fig. 1) (Takahara et al., 2012; Robson et al., 2016; Klymus et al., 2017b). However, prefilters increase cost and larger pore sizes trade capture of smaller particle sizes for greater proportions of target DNA, reducing total eDNA yield (Turner et al., 2014). These issues make it difficult to standardise the exact filtration method or volume of water processed. Nonetheless, species detection rates do not appear to suffer from a larger pore size as the greater volume of water filtered likely compensates for loss of small particle sizes (Goldberg et al., 2018). Similarly, a recent metabarcoding study comparing different filter sizes in ponds found larger filter sizes did not impede detection probability of fish, despite differences in filtration time and eDNA recovery (Li et al., 2018).

In contrast to filtration, water volumes are consistent with ethanol precipitation and species recovery may be the same or higher (Klymus et al., 2017b; Raemy \& Ursenbacher, 2018). However, water volume is usually limited to $\sim 90 \mathrm{ml}$ per sample due to logistical and financial constraints on the number of tubes of ethanol that can be taken into the field (Biggs et al., 2015). Moreover, ethanol is not always easy to obtain and is subject to dangerous goods regulations for transportation. Where possible, we advise filtration is performed on site using enclosed capsule or syringe filters (Spens et al., 2016) to minimise risk of contamination (see Online Resource 2). If on-site filtration is unfeasible, samples should be processed in the laboratory within $24 \mathrm{~h}$ (Hinlo et al., 2017), or preservative solution (e.g. Longmire's, benzalkonium chloride) added if this time frame cannot be met (Williams et al., 2016; Yamanaka et al., 2016), to maximise DNA recovery. Filters should be placed in preservative solution or frozen to prevent eDNA degradation prior to extraction (Hinlo et al., 2017).

\section{Inhibition}

PCR inhibition can affect eDNA samples from any environment (Jane et al., 2015), but the stagnant nature of ponds means they are particularly prone to inhibitor build-up. Ponds have high organic inputs due to dense vegetation, lack of water flow, and soil run-off, which encourages the build-up of algae, supports dense planktonic communities, and leads to high levels of natural turbidity. Turbid water with high suspended particulate matter not only clogs filters, but blocks extraction spin columns reducing DNA recovery. DNA extracts produced from turbid water often contain humic acid and tannin compounds, created through non-enzymatic decay of the organic material. These compounds can inactivate DNA polymerase and inhibit the PCR amplification process, reducing its efficiency or causing complete failure (Alaeddini, 2012; Albers et al., 2013; McKee et al., 2015).

PCR inhibition can cause false negatives, and thus it is imperative that eDNA practitioners and researchers test for it (Goldberg et al., 2016) using qPCR 
amplification of Internal Positive Controls (IPCs, see Table 1), such as Applied Biosystems ${ }^{\mathrm{TM}}$ TaqMan Exogenous Internal Positive Control Reagents (Fig. 1, IPC3), or by spiking reactions with control DNA that will not be found in the sample (Doi et al., 2017). The impact of inhibition can be minimised through optimisation of reagents, protocols, and thermocycling conditions (Alaeddini, 2012; Jane et al., 2015; McKee et al., 2015). Some DNA extraction kits contain specific inhibitor removal steps that can be adapted for use with difficult (e.g. turbid, high algal content) pond eDNA samples (Buxton et al., 2018; Sellers et al., 2018), while stand-alone clean-up kits (e.g. Zymo ${ }^{\circledR}$ or Qiagen ${ }^{\circledR}$ ) can be effective when applied to inhibited samples after DNA extraction (McKee et al., 2015; Williams et al., 2016; Niemillar et al., 2017; Mosher et al., 2018). Alternatively, addition of protein to PCR reactions (e.g. Bovine-serum albumen, BSA) can reduce inhibition (Albers et al., 2013).

Diluting eDNA extracts (Biggs et al., 2015; McKee et al., 2015) or reducing PCR template (Takahara et al., 2015) was previously recommended to overcome inhibition; however, we would not advise either approach. eDNA samples are characterised by low target DNA concentrations and dilution may ultimately reduce target DNA concentration below the limit of detection, causing false negatives despite diluting out inhibiting compounds (Buxton et al., 2017a). Use of droplet digital PCR (ddPCR, see Table 1) may overcome the aforementioned limitations for detection and quantification, particularly in turbid waters containing high concentrations of PCR inhibitors. In ponds, ddPCR outperformed qPCR, especially at very low eDNA concentrations (Doi et al., 2015a), and may be more accurate for abundance or biomass estimation due to lower variability (Nathan et al., 2014; Doi et al., 2015b).

Finally, in addition to running equipment, extraction and amplification blanks, and identification of inhibition using IPCs (Rees et al., 2014b; Goldberg et al., 2016), we recommend that quality control measures are taken to identify sample degradation and extraction efficiency (Fig. 1, IPC1 and 2). A known amount of non-target DNA can be introduced as IPC1 into ethanol precipitation sample kits before they are taken into the field, or non-target DNA can be introduced into a preservative solution for filtered samples. IPC2 can be added before or during the first step of DNA extraction. In similar fashion to IPC3, this sequence would be targeted during qPCR and failure to amplify, or amplification after more cycles than expected, would indicate sample degradation or low extraction efficiency. This will help improve confidence in negative results.

\section{Future perspectives}

Rare and invasive species monitoring

Use of eDNA for presence-absence assessment of rare, threatened, or invasive species has been widely investigated since it was first identified as a major challenge in previous eDNA reviews (Rees et al., 2014b; Thomsen \& Willerslev, 2015). eDNA analysis can complement conventional methods, act as an early warning system for invasive species (Goldberg et al., 2013; Piaggio et al., 2014; Smart et al., 2015; Blackman et al., 2017), and improve distribution mapping and occupancy modelling for rare species (Thomsen et al., 2012; Biggs et al., 2015; Doi et al., 2017; Niemiller et al., 2017; Torresdal et al., 2017). This tool will continue to upscale rare and invasive species monitoring by enabling rapid and cost-efficient screening of multitudes of sites. However, substantial variation exists in design, validation, and application of species-specific assays, even for the same target species, e.g. invasive signal crayfish $P$. leniusculus (Agersnap et al., 2017; Dunn et al., 2017; Larson et al., 2017; Harper et al. 2018a; Mauvisseau et al., 2018; Robinson et al., 2018). False positives and negatives remain pertinent issues in eDNA monitoring and intuitive counter-strategies are required for their mitigation. For purposes of eventual standardisation and consistency of eDNA research independent of target species or environment, researchers must ensure they familiarise themselves with existing guidelines for assay development, such as the Minimum Information for Publication of Quantitative Real-Time PCR Experiments (MIQE) guidelines (Bustin et al., 2009) and the eDNA minimum reporting guidelines established by Goldberg et al. (2016).

Community composition and monitoring at the pondscape

Despite their biodiversity value, monitoring of ponds is problematic due to their high abundance and 
limitations of available sampling tools which may not be representative of key biodiversity (Biggs et al., 2016; Hill et al., 2018). However, eDNA metabarcoding could enable pondscape conservation and management by providing species-level distribution data for entire communities (Harper et al., 2018c). eDNA metabarcoding has been successfully used in ponds to survey temperate and tropical amphibian communities (Valentini et al., 2016; Bálint et al., 2018), fish assemblages (Valentini et al., 2016; Evans et al., 2017), and has strong capacity to detect semiaquatic and terrestrial species (Klymus et al., 2017b; Ushio et al., 2017, 2018b; Harper et al., 2018c).

In contrast to vertebrates, published eDNA metabarcoding studies on pond invertebrates are distinctly lacking despite strong interest in this sector. A small number of studies successfully detected a range of macroinvertebrate taxa from running water (Deiner et al., 2016; Blackman et al., 2017; Klymus et al., 2017a) and lakes (Bista et al., 2017), but these taxa often comprise a low proportion of total sequence reads if generic primers are used (Deiner et al., 2016). The standard barcode gene for which the most extensive reference databases exist, cytochrome c oxidase subunit I (COI, see Hebert et al., 2003), appears to be problematic for eDNA metabarcoding. Often $\mathrm{COI}$ metabarcoding primers (e.g. Meusnier et al., 2008; Zeale et al., 2011; Leray et al., 2013; Elbrecht \& Leese, 2017) do not recover all taxa (Elbrecht et al., 2016) or show substantial amplification bias towards nonmetazoan taxa, for instance, bacteria, fungi, and algae (Brandon-Mong et al., 2015), even when carefully designed to be specific to a particular metazoan group (Elbrecht \& Leese, 2017; Elbrecht et al., 2017). This bias may be more pronounced in ponds containing high densities of phyto- and zooplankton. We recommend that practitioners and researchers employ multiple markers for invertebrate metabarcoding. For example, 16S ribosomal RNA displayed less amplification bias than COI for freshwater invertebrate bulk tissue samples, but reference sequence databases for the former are underdeveloped (Elbrecht et al., 2016). Practitioners and researchers should also focus on the development and application of more specific primers that target particular invertebrate orders or families to reduce amplification bias towards non-target taxa (e.g. Klymus et al., 2017a).

Issues with the metabarcoding approach remain (see Deiner et al., 2017), but species masking should be paid particular attention in ponds. Amplification of highly abundant human and domestic animal DNA in urban and agricultural ponds may prevent detection of wild species (Harper et al., 2018b). However, blocking primers can prevent this amplification bias and have been implemented in eDNA metabarcoding research for investigation of mammal diversity from ancient permafrost (Boessenkool et al., 2012) and pond amphibian and fish communities (Valentini et al., 2016). Metabarcoding has yet to be routinely implemented for monitoring ponds but holds enormous potential for community study. This tool has a number of applications which could improve our knowledge and understanding of pond biodiversity, such as species associations, multi-species distribution and individual pond occupancy, ecological networks, and biomonitoring (Deiner et al., 2017; Elbrecht et al., 2017; Klymus et al., 2017b; Harper et al., 2018c).

\section{Estimation of abundance or biomass}

Estimation of abundance or biomass of target species was previously identified as a major challenge in eDNA research (Rees et al., 2014b; Lawson Handley, 2015; Thomsen \& Willerslev, 2015). Accurate estimation may be most feasible in ponds as their small size may allow well-represented sampling versus large lakes or lotic environments. Some studies have achieved estimates of abundance/biomass from eDNA in ponds (Takahara et al., 2012; Thomsen et al., 2012; Biggs et al., 2015; Buxton et al., 2017b), but others observed no link (Rees et al., 2014a; Doi et al., 2017; Raemy \& Ursenbacher, 2018). Similarly, semi-quantitative estimates have been made from metabarcoding for vertebrate eDNA (Evans et al., 2016; Hänfling et al., 2016; Ushio et al., 2018a) and invertebrate DNA (Elbrecht \& Leese, 2015), but whether these approaches can be applied in ponds and to invertebrate eDNA remain untested. Fully quantitative estimates may also be unrealistic due to potential species masking and amplification bias that occurs when degenerate primers are applied to highly diverse systems (Brandon-Mong et al., 2015; Elbrecht et al., 2016; Deiner et al., 2017; Klymus et al., 2017b; Harper et al., 2018b).

The relationship between eDNA concentration and abundance/biomass is highly variable in natural systems due to the influence of biotic and abiotic factors on release, persistence, and degradation of eDNA 
(Strickler et al., 2015; Buxton et al., 2017a; Goldberg et al., 2018). These factors may be especially influential in ponds, due to their physical and chemical heterogeneity and use by semi-aquatic and terrestrial wildlife. Life stage, behaviour, and seasonality of $T$. cristatus substantially affected eDNA concentration in ponds (Buxton et al., 2017b). Relationships between biomass and eDNA concentration may only be observed during certain life cycle phases, e.g. egg production and spawning (Bylemans et al., 2017; Dunn et al., 2017). Abiotic factors alter rates of organismal eDNA degradation and release, and their effects may be exaggerated in ponds where environmental extremes are observed, e.g. hydroperiod, nutrient loading, pH, conductivity (De Meester et al., 2005; Goldberg et al., 2018). Temperature (Takahara et al., 2012; Robson et al., 2016; Buxton et al., 2017b; Goldberg et al., 2018), pH (Goldberg et al., 2018), and sediment type (Buxton et al., 2017a) were all found to influence eDNA concentration of target species in ponds. Consequently, care must be taken when estimating abundance/biomass of pond species to ensure estimates are not confounded by under-representative sampling, inhibition, and biotic or abiotic variables. Pond eDNA monitoring will continue to benefit from further investigation into the role of organisms and environmental variables (e.g. UV, temperature, $\mathrm{pH}$, anoxia) on eDNA release, persistence, degradation, and detection.

\section{Disease management}

Detection and management of disease in freshwater environments is crucial to preventing spread and further infection. Crayfish plague Aphanomyces astaci (Schikora, 1906) and chytrid fungi Batrachochytrium dendrobatidis (Longcore et al., 1999) and B. salamandrivorans (Martel et al., 2013) pose major threats to pond biodiversity. Chytrid fungi have decimated amphibian populations and contributed to global decline and extinction risk of species (Walker et al., 2007; Mosher et al., 2018). Microscopy or molecular techniques were once used to detect zoosporangium in host individuals but swabs were required from the host's skin or mouth (Mosher et al., 2018). eDNA presented an alternative avenue of diagnosis: water is sampled and filtered, followed by detection of chytrid zoospores using qPCR (Walker et al., 2007; Schmidt et al., 2013; Mosher et al., 2018). A similar procedure was developed to detect crayfish plague spores, carried by invasive North American crayfish but lethal to European crayfish species (Strand et al., 2014), and has since been multiplexed to allow simultaneous qPCR detection of host, vector, and pathogen using eDNA (Robinson et al., 2018). eDNA metabarcoding may be the next logical step to screen for multiple freshwater diseases that threaten biodiversity, or to monitor host, threatened species, and pathogens simultaneously. Microbiome research is another field that has been pivotal to understanding chytrid fungus resistance and immunity in amphibian species, and cure development. Obtaining microbiome data has been dependent on whole body or ventral swabbing, but eDNA metabarcoding of bacterial communities may be an option where tissue samples are not available.

From research to practice

A broad group of stakeholders are invested in eDNA and ponds outside of academia. This group includes commercial ventures, who provide ecological and laboratory services to developers and the building industry; industries (e.g. utility companies) who manage large amounts of land and are responsible for its management/exploitation; government departments and agencies who are responsible for monitoring environmental quality (e.g. Environment Agency, Natural England, Scottish Natural Heritage, United States Fish and Wildlife Service); and end users, which include conservation organisations, the development industry, government departments, and quangos. These end users have identified immediate and long-term priorities for DNA-based environmental monitoring and assessment (DNA End User Group, 2017). They seek methodological advances within eDNA that will allow assessment of ecosystem predictors and/or stressors, and feed into routine biodiversity assessment, monitoring, and other statutory responsibilities. Beyond determining current range, distribution, and response of species to conservation interventions, these advances may include ecological responses to eutrophication and other chemical inputs, spread of invasive species, and range pressures, such as climate change and environmental impact assessment. All of these goals are pertinent to pond conservation and management (pers. comm. UK DNA Working Group). 
In the UK, ponds are now a "Priority Habitat" which may increase incentive for their routine monitoring (JNCC \& Defra, 2012; Hill et al., 2018). Here, eDNA surveys are being adopted to aid pond conservation and steadily incorporated into policy, for example, T. cristatus (Biggs et al., 2014). eDNA results are being used to model $T$. cristatus distribution and inform new Natural England strategic licensing policies that will provide landscape-level species protection, as opposed to site-by-site survey and mitigation which has done little to improve T. cristatus conservation status (Lewis et al., 2016). This policy shift offers a more unified approach to T. cristatus conservation, and pilot projects testing these reforms are underway (see Woking Borough Council report, 2016). eDNA surveys underpinning strategic licensing will provide critical baseline distribution data for $T$. cristatus throughout England, and radically improve understanding of the conservation status of this species.

\section{Conclusions}

eDNA analysis is starting to change the way we design and implement biodiversity monitoring programmes and has opened up new possibilities for the future. This tool holds particular promise in ponds for monitoring biodiversity, testing hypotheses, and understanding eDNA, but there are a number of challenges specific to these environments, in conjunction with those faced by all freshwater habitats. These challenges must be overcome to achieve accurate, standardised tools that can be routinely and reproducibly implemented. At present, there is no consensus on how much water, and how many samples should be taken from an individual pond to achieve representative samples from water that is patchy horizontally, vertically, and temporally. Further investigation is required to determine the number of samples needed to achieve a set detection probability for a target species, or representative community composition. Similarly, methods of eDNA capture diverge widely in ponds between filtration (various pore sizes and filter types) and ethanol precipitation. Evidence suggests that pond water samples should be processed by filtration, but intuitive strategies are needed to prevent clogging. All captured and extracted DNA requires PCR amplification, whether PCR, qPCR, or ddPCR, but PCR inhibition remains a pressing issue in pond eDNA monitoring. It is therefore crucial that researchers and practitioners test for and report steps taken to prevent inhibition of the amplification process. A broad standardisation of eDNA workflows (with flexibility depending on sample type and downstream application) will ensure more robust, comparable, and ecologically meaningful data to guide effective management and conservation of pond biodiversity, without stifling innovation or development. This process has begun in Europe with the establishment of DNAqua-net: a network of researchers and end users invested in the development of gold-standard molecular tools and indices for biodiversity assessment and biomonitoring of water bodies. DNAqua-net is composed of five working groups that contribute to these overarching goals: DNA Barcode References, Biotic Indices and Metrics, Field and Lab Protocols, Data Analysis and Storage, Implementation Strategy and Legal Issues (Leese et al., 2016). We are now beginning to see outputs from the DNAqua-net working groups (Hering et al., 2018; http://dnaqua.net/publications/) that will guide standardisation and improve molecular monitoring of European freshwater ecosystems.

Open Access This article is distributed under the terms of the Creative Commons Attribution 4.0 International License (http:// creativecommons.org/licenses/by/4.0/), which permits unrestricted use, distribution, and reproduction in any medium, provided you give appropriate credit to the original author(s) and the source, provide a link to the Creative Commons license, and indicate if changes were made.

Author contributions LRH and ASB conceived the review and organised the stakeholder workshop held in 2017 to discuss opportunities and challenges of eDNA monitoring in ponds. LRH, ASB, HCR, KB, DH, HVW, and GB attended the workshop which was hosted by DSR at Centre for Ecology and Hydrology, Wallingford. LRH and ASB wrote the manuscript, which all authors revised.

\section{References}

Agersnap, S., W. B. Larsen, S. W. Knudsen, D. Strand, P. F. Thomsen, M. Hesselsøe, P. B. Mortensen, T. Vrålstad \& P. R. Møller, 2017. Monitoring of noble, signal and narrow-clawed crayfish using environmental DNA from freshwater samples. PLoS ONE 12: e0179261.

Alaeddini, R., 2012. Forensic implications of PCR inhibition-a review. Forensic Science International: Genetics 6: 297-305. 
Albers, C. N., A. Jensen, J. Bælum \& C. S. Jacobsen, 2013. Inhibition of DNA polymerases used in Q-PCR by structurally different soil-derived humic substances. Geomicrobiology Journal 30: 675-681.

Alderton, E., C. D. Sayer, R. Davies, S. J. Lambert \& J. C. Axmacher, 2017. Buried alive: aquatic plants survive in "ghost ponds" under agricultural fields. Biological Conservation 212: 105-110.

Bálint, M., C. Nowak, O. Márton, S. U. Pauls, C. Wittwer, J. L. Aramayo, A. Schulze, T. Chambert, B. Cocchiararo \& M. Jansen, 2018. Accuracy, limitations and cost efficiency of eDNA-based community survey in tropical frogs. Molecular Ecology Resources. https://doi.org/10.1111/ 1755-0998.12934

Barnes, M. A. \& C. R. Turner, 2015. The ecology of environmental DNA and implications for conservation genetics. Conservation Genetics 17: 1-17.

Biggs, J., N. Ewald, A. Valentini, C. Gaboriaud, \& R. A. Griffiths, 2014. Analytical and Methodological Development for Improved Surveillance of the Great Crested Newt. Defra Project WC1067.

Biggs, J., N. Ewald, A. Valentini, C. Gaboriaud, T. Dejean, R. A. Griffiths, J. Foster, J. W. Wilkinson, A. Arnell, P. Brotherton, P. Williams \& F. Dunn, 2015. Using eDNA to develop a national citizen science-based monitoring programme for the great crested newt (Triturus cristatus). Biological Conservation 183: 19-28.

Biggs, J., S. von Fumetti \& M. Kelly-Quinn, 2016. The importance of small waterbodies for biodiversity and ecosystem services: implications for policy makers. Hydrobiologia 793: 3-39.

Bista, I., G. R. Carvalho, K. Walsh, M. Seymour, M. Hajibabaei, D. Lallias, M. Christmas \& S. Creer, 2017. Annual timeseries analysis of aqueous eDNA reveals ecologically relevant dynamics of lake ecosystem biodiversity. Nature Communications 8: 14087.

Blackman, R. C., D. Constable, C. Hahn, A. M. Sheard, J. Durkota, B. Hänfling \& L. L. Handley, 2017. Detection of a new non-native freshwater species by DNA metabarcoding of environmental samples-first record of Gammarus fossarum in the UK. Aquatic Invasions 12: 177-189.

Boessenkool, S., L. S. Epp, J. Haile, E. Bellemain, M. Edwards, E. Coissac, E. Willerslev, C. Brochmann, 2012. Blocking human contaminant DNA during PCR allows amplification of rare mammal species from sedimentary ancient DNA. Molecular Ecology 21: 1806-1815.

Brandon-Mong, G.-J., H.-M. Gan, K.-W. Sing, P.-S. Lee, P.-E. Lim \& J.-J. Wilson, 2015. DNA metabarcoding of insects and allies: an evaluation of primers and pipelines. Bulletin of Entomological Research 105: 717-727.

Briers, R. A. \& J. Biggs, 2005. Spatial patterns in pond invertebrate communities: separating environmental and distance effects. Aquatic Conservation: Marine and Freshwater Ecosystems 15: 549-557.

Bustin, S. A., V. Benes, J. A. Garson, J. Hellemans, J. Huggett, M. Kubista, R. Mueller, T. Nolan, M. W. Pfaffl, G. L. Shipley, J. Vandesompele \& C. T. Wittwer, 2009. The MIQE guidelines: minimum information for publication of quantitative real-time PCR experiments. Clinical Chemistry 55: 611-622.
Buxton, A. S., J. J. Groombridge \& R. A. Griffiths, 2017a. Is the detection of aquatic environmental DNA influenced by substrate type? PLoS ONE 12: e0183371.

Buxton, A. S., J. J. Groombridge, N. B. Zakaria \& R. A. Griffiths, 2017b. Seasonal variation in environmental DNA in relation to population size and environmental factors. Scientific Reports 7: 46294.

Buxton, A. S., J. J. Groombridge \& R. A. Griffiths, 2018. Seasonal variation in environmental DNA detection in sediment and water samples. PLoS ONE 13: e0191737.

Bylemans, J., E. M. Furlan, C. M. Hardy, P. McGuffie, M. Lintermans \& D. M. Gleeson, 2017. An environmental DNA-based method for monitoring spawning activity: a case study, using the endangered Macquarie perch (Macquaria australasica). Methods in Ecology and Evolution 8: 646-655.

Céréghino, R., J. Biggs, B. Oertli \& S. Declerck, 2008. The ecology of European ponds: defining the characteristics of a neglected freshwater habitat. Hydrobiologia 597: 1-6.

Davies, B., J. Biggs, P. Williams, M. Whitfield, P. Nicolet, D. Sear, S. Bray \& S. Maund, 2008. Comparative biodiversity of aquatic habitats in the European agricultural landscape. Agriculture, Ecosystems \& Environment 125: 1-8.

Deiner, K., H. M. Bik, E. Mächler, M. Seymour, A. LacoursièreRoussel, F. Altermatt, S. Creer, I. Bista, D. M. Lodge, N. de Vere, M. E. Pfrender \& L. Bernatchez, 2017. Environmental DNA metabarcoding: transforming how we survey animal and plant communities. Molecular Ecology 26: 5872-5895.

Deiner, K., E. A. Fronhofer, E. Mächler, J.-C. Walser \& F. Altermatt, 2016. Environmental DNA reveals that rivers are conveyer belts of biodiversity information. Nature Communications 7: 12544.

De Meester, L., S. Declerck, R. Stoks, G. Louette, F. Van De Meutter, T. De Bie, E. Michels \& L. Brendonck, 2005. Ponds and pools as model systems in conservation biology, ecology and evolutionary biology. Aquatic Conservation: Marine and Freshwater Ecosystems 15: 715-725.

de Souza, L. S., J. C. Godwin, M. A. Renshaw \& E. Larson, 2016. Environmental DNA (eDNA) detection probability is influenced by seasonal activity of organisms. PLoS ONE 11: e0165273.

DNA End User Group, 2017. DNA End User Group - DNA based method development interests. Accessed on 10th January 2018.

Doi, H., T. Takahara, T. Minamoto, S. Matsuhashi, K. Uchii \& H. Yamanaka, 2015a. Droplet digital polymerase chain reaction (PCR) outperforms real-time PCR in the detection of environmental DNA from an invasive fish species. Environmental Science \& Technology 49: 5601-5608.

Doi, H., K. Uchii, T. Takahara, S. Matsuhashi, H. Yamanaka \& T. Minamoto, 2015b. Use of droplet digital PCR for estimation of fish abundance and biomass in environmental DNA surveys. PLoS ONE 10: e0122763.

Doi, H., I. Katano, Y. Sakata, R. Souma, T. Kosuge, M. Nagano, K. Ikeda, K. Yano \& K. Tojo, 2017. Detection of an endangered aquatic heteropteran using environmental DNA in a wetland ecosystem. Royal Society Open Science 4: 170568. 
Downing, J. A., Y. T. Prairie, J. J. Cole, C. M. Duarte, L. J. Tranvik, R. G. Striegl, W. H. McDowell, P. Kortelainen, N. F. Caraco, J. M. Melack \& J. J. Middelburg, 2006. The global abundance and size distribution of lakes, ponds, and impoundments. Limnology and Oceanography 51: 2388-2397.

Dunker, K. J., A. J. Sepulveda, R. L. Massengill, J. B. Olsen, O. L. Russ, J. K. Wenburg \& A. Antonovich, 2016. Potential of environmental DNA to evaluate Northern Pike (Esox lucius) eradication efforts: an experimental test and case study. PLoS ONE 11: e0162277.

Dunn, N., V. Priestley, A. Herraiz, R. Arnold \& V. Savolainen, 2017. Behavior and season affect crayfish detection and density inference using environmental DNA. Ecology and Evolution 7: 7777-7785.

Eichmiller, J. J., P. G. Bajer \& P. W. Sorensen, 2014. The relationship between the distribution of common carp and their environmental DNA in a small lake. PLoS ONE 9: e112611.

Elbrecht, V. \& F. Leese, 2015. Can DNA-based ecosystem assessments quantify species abundance? Testing primer bias and biomass-sequence relationships with an innovative metabarcoding protocol. PLoS ONE 10: e0130324.

Elbrecht, V. \& F. Leese, 2017. Validation and development of COI metabarcoding primers for freshwater macroinvertebrate bioassessment. Frontiers in Environmental Science 5: $1-11$.

Elbrecht, V., P. Taberlet, T. Dejean, A. Valentini, P. UsseglioPolatera, J.-N. Beisel, E. Coissac, F. Boyer \& F. Leese, 2016. Testing the potential of a ribosomal 16S marker for DNA metabarcoding of insects. PeerJ 4: e1966.

Elbrecht, V., E. E. Vamos, K. Meissner, J. Aroviita \& F. Leese, 2017. Assessing strengths and weaknesses of DNA metabarcoding-based macroinvertebrate identification for routine stream monitoring. Methods in Ecology and Evolution 8: 1265-1275.

Emson, D., C. D. Sayer, H. Bennion, I. R. Patmore \& P. Rioual, 2017. Mission possible: diatoms can be used to infer past duckweed (lemnoid Araceae) dominance in ponds. Journal of Paleolimnology 60: 209-221.

Evans, N. T., B. P. Olds, M. A. Renshaw, C. R. Turner, Y. Li, C. L. Jerde, A. R. Mahon, M. E. Pfrender, G. A. Lamberti \& D. M. Lodge, 2016. Quantification of mesocosm fish and amphibian species diversity via environmental DNA metabarcoding. Molecular Ecology Resources 16: 29-41.

Evans, N. T., Y. Li, M. A. Renshaw, B. P. Olds, K. Deiner, C. R. Turner, C. L. Jerde, D. M. Lodge, G. A. Lamberti \& M. E. Pfrender, 2017. Fish community assessment with eDNA metabarcoding: effects of sampling design and bioinformatic filtering. Canadian Journal of Fisheries and Aquatic Sciences 74: 1362-1374.

Ficetola, G. F., C. Miaud, F. Pompanon \& P. Taberlet, 2008. Species detection using environmental DNA from water samples. Biology Letters 4: 423-425.

Goldberg, C. S., A. Sepulveda, A. Ray, J. Baumgardt \& L. P. Waits, 2013. Environmental DNA as a new method for early detection of New Zealand mudsnails (Potamopyrgus antipodarum). Freshwater Science 32: 792-800.

Goldberg, C. S., C. R. Turner, K. Deiner, K. E. Klymus, P. F. Thomsen, M. A. Murphy, S. F. Spear, A. McKee, S. J. Oyler-McCance, R. S. Cornman, M. B. Laramie, A.
R. Mahon, R. F. Lance, D. S. Pilliod, K. M. Strickler, L. P. Waits, A. K. Fremier, T. Takahara, J. E. Herder \& P. Taberlet, 2016. Critical considerations for the application of environmental DNA methods to detect aquatic species. Methods in Ecology and Evolution 7: 1299-1307.

Goldberg, C. S., K. M. Strickler \& A. K. Fremier, 2018. Degradation and dispersion limit environmental DNA detection of rare amphibians in wetlands: increasing efficacy of sampling designs. Science of the Total Environment 633: 695-703.

Hänfling, B., L. Lawson Handley, D. S. Read, C. Hahn, J. Li, P. Nichols, R. C. Blackman, A. Oliver \& I. J. Winfield, 2016. Environmental DNA metabarcoding of lake fish communities reflects long-term data from established survey methods. Molecular Ecology 25: 3101-3119.

Harper, K. J., N. Patrick Anucha, J. F. Turnbull, C. W. Bean \& M. J. Leaver, 2018a. Searching for a signal: environmental DNA (eDNA) for the detection of invasive signal crayfish, Pacifastacus leniusculus (Dana, 1852). Management of Biological Invasions 9: 137-148.

Harper, L. R., L. Lawson Handley, C. Hahn, N. Boonham, H. C. Rees, K. C. Gough, E. Lewis, I. P. Adams, P. Brotherton, S. Phillips \& B. Hänfling, 2018b. Needle in a haystack? A comparison of eDNA metabarcoding and targeted qPCR for detection of the great crested newt (Triturus cristatus). Ecology and Evolution 8: 6330-6341.

Harper, L. R., L. Lawson Handley, C. Hahn, N. Boonham, H. C. Rees, E. Lewis, I. P. Adams, P. Brotherton, S. Phillips \& B. Hänfling, 2018c. Ground-truthing environmental DNA metabarcoding for ecological hypothesis testing at the pondscape. bioRxiv. https://doi.org/10.1101/278309.

Hebert, P. D. N., A. Cywinska, S. L. Ball \& J. R. deWaard, 2003. Biological identifications through DNA barcodes. Proceedings of the Royal Society of London B: Biological Sciences 270: 313-321.

Hering, D., A. Borja, J. I. Jones, D. Pont, P. Boets, A. Bouchez, K. Bruce, S. Drakare, B. Hänfling, M. Kahlert, F. Leese, K. Meissner, P. Mergen, Y. Reyjol, P. Segurado, A. Vogler \& M. Kelly, 2018. Implementation options for DNA-based identification into ecological status assessment under the European Water Framework Directive. Water Research 138: 192-205.

Hill, M. J., C. Hassall, B. Oertli, L. Fahrig, B. J. Robson, J. Biggs, M. J. Samways, N. Usio, N. Takamura, J. Krishnaswamy \& P. J. Wood, 2018. New policy directions for global pond conservation. Conservation Letters 142: e12447.

Hinlo, R., D. Gleeson, M. Lintermans \& E. Furlan, 2017. Methods to maximise recovery of environmental DNA from water samples. PLoS ONE 12: e0179251.

Jane, S. F., T. M. Wilcox, K. S. McKelvey, M. K. Young, M. K. Schwartz, W. H. Lowe, B. H. Letcher \& A. R. Whiteley, 2015. Distance, flow and PCR inhibition: eDNA dynamics in two headwater streams. Molecular Ecology Resources 15: 216-227.

JNCC, \& Defra, 2012. UK post-2010 biodiversity framework. Joint Nature Conservation Committee, Peterborough. Accessed on 10th January 2018. http://jncc.defra.gov.uk/ page-6189.

Kazanjian, G., S. Flury, K. Attermeyer, T. Kalettka, A. Kleeberg, K. Premke, J. Köhler \& S. Hilt, 2018. Primary 
production in nutrient-rich kettle holes and consequences for nutrient and carbon cycling. Hydrobiologia 806: 77-93.

Klymus, K. E., N. T. Marshall \& C. A. Stepien, 2017a. Environmental DNA (eDNA) metabarcoding assays to detect invasive invertebrate species in the Great Lakes. PLoS ONE 12: e0177643.

Klymus, K. E., C. A. Richter, N. Thompson \& J. E. Hinck, 2017b. Metabarcoding of environmental DNA samples to explore the use of uranium mine containment ponds as a water source for wildlife. Diversity 9: 54.

Larson, E. R., M. A. Renshaw, C. A. Gantz, J. Umek, S. Chandra, D. M. Lodge \& S. P. Egan, 2017. Environmental DNA (eDNA) detects the invasive crayfishes Orconectes rusticus and Pacifastacus leniusculus in large lakes of North America. Hydrobiologia 800: 173-185.

Lawson Handley, L., 2015. How will the "molecular revolution" contribute to biological recording? Biological Journal of the Linnean Society 115: 750-766.

Leese, F., F. Altermatt, A. Bouchez, T. Ekrem, D. Hering, K. Meissner, P. Mergen, J. Pawlowski, J. Piggott, F. Rimet, D. Steinke, P. Taberlet, A. Weigand, K. Abarenkov, P. Beja, L. Bervoets, S. Björnsdóttir, P. Boets, A. Boggero, A. Bones, Á. Borja, K. Bruce, V. Bursić, J. Carlsson, F. Čiampor, Z. Čiamporová-Zatovičová, E. Coissac, F. Costa, M. Costache, S. Creer, Z. Csabai, K. Deiner, Á. DelValls, S. Drakare, S. Duarte, T. Eleršek, S. Fazi, C. Fišer, J.-F. Flot, V. Fonseca, D. Fontaneto, M. Grabowski, W. Graf, J. Guðbrandsson, M. Hellström, Y. Hershkovitz, P. Hollingsworth, B. Japoshvili, J. Jones, M. Kahlert, B. Kalamujic Stroil, P. Kasapidis, M. Kelly, M. Kelly-Quinn, E. Keskin, U. Kõljalg, Z. Ljubešić, I. Maček, E. Mächler, A. Mahon, M. Marečková, M. Mejdandzic, G. Mircheva, M. Montagna, C. Moritz, V. Mulk, A. Naumoski, I. Navodaru, J. Padisák, S. Pálsson, K. Panksep, L. Penev, A. Petrusek, M. Pfannkuchen, C. Primmer, B. Rinkevich, A. Rotter, A. Schmidt-Kloiber, P. Segurado, A. Speksnijder, P. Stoev, M. Strand, S. Šulčius, P. Sundberg, M. Traugott, C. Tsigenopoulos, X. Turon, A. Valentini, B. van der Hoorn, G. Várbíró, M. Vasquez Hadjilyra, J. Viguri, I. Vitonytè, A. Vogler, T. Vrålstad, W. Wägele, R. Wenne, A. Winding, G. Woodward, B. Zegura \& J. Zimmermann, 2016. DNAquaNet: developing new genetic tools for bioassessment and monitoring of aquatic ecosystems in Europe. Research Ideas and Outcomes 2: e11321.

Leray, M., J. Y. Yang, C. P. Meyer, S. C. Mills, N. Agudelo, V. Ranwez, J. T. Boehm \& R. J. Machida, 2013. A new versatile primer set targeting a short fragment of the mitochondrial COI region for metabarcoding metazoan diversity: application for characterizing coral reef fish gut contents. Frontiers in Zoology 10: 34.

Lewis, B., R. A. Griffiths \& J. W. Wilkinson, 2016. Population status of great crested newts (Triturus cristatus) at sites subjected to development mitigation. The Herpetological Journal 27: 133-142.

Li, J., L. Lawson Handley, D. S. Read \& B. Hänfling, 2018. The effect of filtration method on the efficiency of environmental DNA capture and quantification via metabarcoding. Molecular Ecology Resources 18: 1102-1114.

Longcore, J. E., A. P. Pessier \& D. K. Nichols, 1999. Batrachochytrium Dendrobatidis gen. et sp. nov., a chytrid pathogenic to amphibians. Mycologia 91: 219-227.
Martel, A., A. Spitzen-van der Sluijs, M. Blooi, W. Bert, R. Ducatelle, M. C. Fisher, A. Woeltjes, W. Bosman, K. Chiers, F. Bossuyt \& F. Pasmans, 2013. Batrachochytrium salamandrivorans sp. nov. causes lethal chytridiomycosis in amphibians. Proceedings of the National Academy of Sciences of the United States of America 110: 15325-15329.

Mauvisseau, Q., A. Coignet, C. Delaunay, F. Pinet, D. Bouchon \& C. Souty-Grosset, 2018. Environmental DNA as an efficient tool for detecting invasive crayfishes in freshwater ponds. Hydrobiologia 805: 163-175.

McKee, A. M., S. F. Spear \& T. W. Pierson, 2015. The effect of dilution and the use of a post-extraction nucleic acid purification column on the accuracy, precision, and inhibition of environmental DNA samples. Biological Conservation 183: 70-76.

Meusnier, I., G. A. C. Singer, J.-F. Landry, D. A. Hickey, P. D. N. Hebert \& M. Hajibabaei, 2008. A universal DNA mini-barcode for biodiversity analysis. BMC genomics 9: 214.

Mosher, B. A., K. P. Huyvaert \& L. L. Bailey, 2018. Beyond the swab: ecosystem sampling to understand the persistence of an amphibian pathogen. Oecologia 188: 319-330.

Nathan, L. M., M. Simmons, B. J. Wegleitner, C. L. Jerde \& A. R. Mahon, 2014. Quantifying environmental DNA signals for aquatic invasive species across multiple detection platforms. Environmental Science \& Technology 48: 12800-12806.

Nicolet, P., J. Biggs, G. Fox, M. J. Hodson, C. Reynolds, M. Whitfield \& P. Williams, 2004. The wetland plant and macroinvertebrate assemblages of temporary ponds in England and Wales. Biological Conservation 120: 261-278.

Niemiller, M. L., M. L. Porter, J. Keany, H. Gilbert, D. W. Fong, D. C. Culver, C. S. Hobson, K. D. Kendall, M. A. Davis \& S. J. Taylor, 2017. Evaluation of eDNA for groundwater invertebrate detection and monitoring: a case study with endangered Stygobromus (Amphipoda: Crangonyctidae). Conservation Genetics Resources 10: 247-257.

Piaggio, A. J., R. M. Engeman, M. W. Hopken, J. S. Humphrey, K. L. Keacher, W. E. Bruce \& M. L. Avery, 2014. Detecting an elusive invasive species: a diagnostic PCR to detect Burmese python in Florida waters and an assessment of persistence of environmental DNA. Molecular Ecology Resources 14: 374-380.

Raemy, M. \& S. Ursenbacher, 2018. Detection of the European pond turtle (Emys orbicularis) by environmental DNA: is eDNA adequate for reptiles? Amphibia-Reptilia 39: 135-143.

Rees, H. C., K. Bishop, D. J. Middleditch, J. R. M. Patmore, B. C. Maddison \& K. C. Gough, 2014a. The application of eDNA for monitoring of the Great Crested Newt in the UK. Ecology and Evolution 4: 4023-4032.

Rees, H. C., B. C. Maddison, D. J. Middleditch, J. R. M. Patmore \& K. C. Gough, 2014b. REVIEW: The detection of aquatic animal species using environmental DNA - a review of eDNA as a survey tool in ecology. Journal of Applied Ecology 51: 1450-1459.

Rees, H. C., C. A. Baker, D. S. Gardner, B. C. Maddison \& K. C. Gough, 2017. The detection of great crested newts year 
round via environmental DNA analysis. BMC Research Notes 10: 327.

Robinson, C. V., T. M. U. Webster, J. Cable, J. James \& S. Consuegra, 2018. Simultaneous detection of invasive signal crayfish, endangered white-clawed crayfish and the crayfish plague pathogen using environmental DNA. Biological Conservation 222: 241-252.

Robson, H. L. A., T. H. Noble, R. J. Saunders, S. K. A. Robson, D. W. Burrows \& D. R. Jerry, 2016. Fine tuning for the tropics: application of eDNA technology for invasive fish detection in tropical freshwater ecosystems. Molecular Ecology Resources 16: 922-932.

Sayer, C., E. Shilland, H. Greaves, B. Dawson, I. Patmore, D. Emson, E. Alderton, P. Robinson, K. Andrews, J. Axmacher \& E. Wiik, 2013. Managing Britain's ponds-conservation lessons from a Norfolk farm. British Wildlife 25: 21-28.

Schmidt, B. R., K. Marc, S. Ursenbacher, O. J. Hyman \& J. P. Collins, 2013. Site occupancy models in the analysis of environmental DNA presence/absence surveys: a case study of an emerging amphibian pathogen. Methods in Ecology and Evolution 4: 646-653.

Sellers, G. S., C. Di Muri, A. Gómez \& B. Hänfling, 2018. MuDNA: a modular universal DNA extraction method adaptable for a wide range of sample types. Metabarcoding and Metagenomics 2: e24556.

Smart, A. S., R. Tingley, A. R. Weeks, A. R. van Rooyen \& M. A. McCarthy, 2015. Environmental DNA sampling is more sensitive than a traditional survey technique for detecting an aquatic invader. Ecological Applications 25: 1944-1952.

Spear, S. F., J. D. Groves, L. A. Williams \& L. P. Waits, 2015. Using environmental DNA methods to improve detectability in a hellbender (Cryptobranchus alleganiensis) monitoring program. Biological Conservation 183: 38-45.

Spens, J., A. R. Evans, D. Halfmaerten, S. W. Knudsen, M. E. Sengupta, S. S. T. Mak, E. E. Sigsgaard \& M. Hellström, 2016. Comparison of capture and storage methods for aqueous macrobial eDNA using an optimized extraction protocol: advantage of enclosed filter. Methods in Ecology and Evolution 8: 635-645.

Strand, D. A., J. Jussila, S. I. Johnsen, S. Viljamaa-Dirks, L. Edsman, J. Wiik-Nielsen, H. Viljugrein, F. Engdahl \& T. Vrålstad, 2014. Detection of crayfish plague spores in large freshwater systems. Journal of Applied Ecology 51: 544-553.

Strickler, K. M., A. K. Fremier \& C. S. Goldberg, 2015. Quantifying effects of UV-B, temperature, and $\mathrm{pH}$ on eDNA degradation in aquatic microcosms. Biological Conservation 183: 85-92.

Takahara, T., T. Minamoto, H. Yamanaka, H. Doi \& Z. Kawabata, 2012. Estimation of fish biomass using environmental DNA. PLoS ONE 7: e35868.

Takahara, T., T. Minamoto \& H. Doi, 2015. Effects of sample processing on the detection rate of environmental DNA from the Common Carp (Cyprinus carpio). Biological Conservation 183: 64-69.

Takahashi, M. K., M. J. Meyer, C. Mcphee, J. R. Gaston, M. D. Venesky \& B. F. Case, 2018. Seasonal and diel signature of eastern hellbender environmental DNA. The Journal of Wildlife Management 82: 217-225.

Thomsen, P. F. \& E. Willerslev, 2015. Environmental DNA-an emerging tool in conservation for monitoring past and present biodiversity. Biological Conservation 183: 4-18.

Thomsen, P. F., L. L. Iversen, C. Wiuf, M. Rasmussen, M. T. P. Gilbert, L. Orlando \& E. Willerslev, 2012. Monitoring endangered freshwater biodiversity using environmental DNA. Molecular Ecology 21: 2565-2573.

Tillotson, M. D., R. P. Kelly, J. J. Duda, M. Hoy, J. Kralj \& T. P. Quinn, 2018. Concentrations of environmental DNA (eDNA) reflect spawning salmon abundance at fine spatial and temporal scales. Biological Conservation 220: 1-11.

Torresdal, J. D., A. D. Farrell \& C. S. Goldberg, 2017. Environmental DNA detection of the golden tree Frog (Phytotriades auratus) in Bromeliads. PLoS ONE 12: e0168787.

Tréguier, A., J.-M. Paillisson, T. Dejean, A. Valentini, M. A. Schlaepfer \& J.-M. Roussel, 2014. Environmental DNA surveillance for invertebrate species: advantages and technical limitations to detect invasive crayfish Procambarus clarkii in freshwater ponds. Journal of Applied Ecology 51: 871-879.

Turner, C. R., M. A. Barnes, C. C. Y. Xu, S. E. Jones, C. L. Jerde \& D. M. Lodge, 2014. Particle size distribution and optimal capture of aqueous macrobial eDNA. Methods in Ecology and Evolution 5: 676-684.

Turner, C. R., K. L. Uy \& R. C. Everhart, 2015. Fish environmental DNA is more concentrated in aquatic sediments than surface water. Biological Conservation 183: 93-102.

Ushio, M., H. Fukuda, T. Inoue, K. Makoto, O. Kishida, K. Sato, K. Murata, M. Nikaido, T. Sado, Y. Sato, M. Takeshita, W. Iwasaki, H. Yamanaka, M. Kondoh \& M. Miya, 2017. Environmental DNA enables detection of terrestrial mammals from forest pond water. Molecular Ecology Resources 17: e63-e65.

Ushio, M., H. Murakami, R. Masuda, T. Sado, M. Miya, S. Sakurai, H. Yamanaka, T. Minamoto \& M. Kondoh, 2018a. Quantitative monitoring of multispecies fish environmental DNA using high-throughput sequencing. Metabarcoding and Metagenomics 2: e23297.

Ushio, M., K. Murata, T. Sado, I. Nishiumi, M. Takeshita, W. Iwasaki \& M. Miya, 2018b. Demonstration of the potential of environmental DNA as a tool for the detection of avian species. Scientific Reports 8: 4493.

Valentini, A., P. Taberlet, C. Miaud, R. Civade, J. Herder, P. F. Thomsen, E. Bellemain, A. Besnard, E. Coissac, F. Boyer, C. Gaboriaud, P. Jean, N. Poulet, N. Roset, G. H. Copp, P. Geniez, D. Pont, C. Argillier, J.-M. Baudoin, T. Peroux, A. J. Crivelli, A. Olivier, M. Acqueberge, M. Le Brun, P. R. Møller, E. Willerslev \& T. Dejean, 2016. Nextgeneration monitoring of aquatic biodiversity using environmental DNA metabarcoding. Molecular Ecology 25: 929-942.

Walker, S. F., M. B. Salas, D. Jenkins, T. W. J. Garner, A. A. Cunningham, A. D. Hyatt, J. Bosch \& M. C. Fisher, 2007. Environmental detection of Batrachochytrium dendrobatidis in a temperate climate. Diseases of Aquatic Organisms 77: 105-112.

Weltz, K., J. M. Lyle, J. Ovenden, J. A. T. Morgan, D. A. Moreno \& J. M. Semmens, 2017. Application of 
environmental DNA to detect an endangered marine skate species in the wild. PLoS ONE 12: e0178124.

Williams, K. E., K. P. Huyvaert \& A. J. Piaggio, 2016. No filters, no fridges: a method for preservation of water samples for eDNA analysis. BMC Research Notes 9: 298.

Wood, P. J., M. T. Greenwood \& M. D. Agnew, 2003. Pond biodiversity and habitat loss in the UK. Area 35: 206-216.

Woking Borough Council, 2016. Natural Woking Biodiversity and Green Infrastructure Strategy Supporting Information, 118-131. Accessed on 10th January 2018. Available at: https://www.woking.gov.uk/environment/greeninf/ naturalwoking/nwsuppinfo.
Yamanaka, H., T. Minamoto, J. Matsuura, S. Sakurai, S. Tsuji, H. Motozawa, M. Hongo, Y. Sogo, N. Kakimi, I. Teramura, M. Sugita, M. Baba \& A. Kondo, 2016. A simple method for preserving environmental DNA in water samples at ambient temperature by addition of cationic surfactant. Limnology 18: 233-241.

Zeale, M. R. K., R. K. Butlin, G. L. A. Barker, D. C. Lees \& G. Jones, 2011. Taxon-specific PCR for DNA barcoding arthropod prey in bat faeces. Molecular Ecology Resources 11: $236-244$. 